\title{
Evidence that protease action is not specifically involved in the hatching of rabbit blastocysts caused by commercial bovine serum albumin in culture
}

\author{
M. T. Kane \\ Department of Physiology, University College, Galway, Ireland
}

\begin{abstract}
Summary. Commercial samples of bovine serum albumin (BSA) in a complex medium caused growth of 1-cell rabbit embryos to completely hatched blastocysts. Heat treatment of the BSA at 65 or $80^{\circ} \mathrm{C}$ significantly decreased blastocyst formation and expansion and destroyed the ability to cause blastocyst hatching. Addition of trypsin at levels down to $20 \mathrm{ng} / \mathrm{ml}$ caused the formation of hatched blastocysts which degenerated rapidly. The effects of 5 protease inhibitors (ovomucoid trypsin inhibitor, $\alpha-1$ antitrypsin, TAME, TLCK and soyabean) were tested. Ovomucoid trypsin inhibitor, TAME and TLCK significantly inhibited blastocyst hatching but only at the highest concentration used. These inhibitors also reduced blastocyst formation and expansion, indicating that their effect was not specifically on blastocyst hatching in vitro. It is concluded that hatching of rabbit blastocysts is probably not dependent on protease action.
\end{abstract}

\section{Introduction}

Commercial samples of crystallized bovine serum albumin (BSA) have been found to cause complete hatching or zona shedding of rabbit blastocysts cultured in vitro from the one-cell stage (Kane, 1972; Kane \& Headon, 1980). This effect appeared to be due to a relatively high molecular weight protein contaminant of the BSA or a smaller molecule associated with such a contaminant (Kane \& Headon, 1980).

Because the role of proteases in eroding rabbit blastocyst coverings in vivo has been well documented (Denker, 1977) the present study explored the possibility that the hatching of rabbit blastocysts in culture is due to protease action either by an endogenous protease produced by the blastocyst or by a protease contaminant of the BSA.

\section{Materials and Methods}

Embryos. New Zealand White does were induced to superovulate by treatment with FSH (twice daily s.c. injections for 3 days : $0.5 \mathrm{mg}$ /injection) followed 1 day later by simultaneous injection of LH (0.5 mg, i.v.) and artificial insemination. One-cell embryos were collected $20-21 \mathrm{~h}$ after injection of LH. FSH and LH were pituitary preparations from Armour (Kankakee, Illinois, U.S.A.). The composition of the flushing medium was $0 \cdot 1 \%$ defatted $\mathrm{BSA}, 126 \mathrm{mM}-\mathrm{NaCl}, 4 \cdot 78 \mathrm{mM}-$ $\mathrm{KCl}, 1 \cdot 71 \mathrm{~mm}-\mathrm{CaCl}_{2} .2 \mathrm{H}_{2} \mathrm{O}, 1 \cdot 19 \mathrm{~mm}-\mathrm{KH}_{2} \mathrm{PO}_{4}, 1 \cdot 19 \mathrm{mM}-\mathrm{MgSO}_{4} .7 \mathrm{H}_{2} \mathrm{O}, 10 \mathrm{mM}-\mathrm{Hepes}$ and 500 i.u. penicillin $\mathrm{G} / \mathrm{ml}$ and $500 \mu \mathrm{g}$ streptomycin sulphate $/ \mathrm{ml}$. This medium was neutralized to $\mathrm{pH} 7.4$ at $37^{\circ} \mathrm{C}$ with $1 \mathrm{~N}-\mathrm{NaOH}$. Embryos were washed free of oviduct fluid with repeated changes of the 
flushing medium and were placed in culture in $0.5 \mathrm{ml}$ droplets of culture medium under liquid paraffin in tissue culture dishes. Culture dishes were maintained at $38^{\circ} \mathrm{C}$ under a gas phase of $5 \%$ $\mathrm{CO}_{2}$ in air. Embryos were cultured for 6 days and the numbers of early blastocysts (blastocoele just visible), expanding blastocysts (blastocysts beginning to expand and thin the zona) and hatched blastocysts (zona shed completely) were recorded. Any mucin coat present was always shed with the zona.

Culture medium. The basic culture medium contained $108 \mathrm{~mm}-\mathrm{NaCl}, 4 \cdot 78 \mathrm{~mm}-\mathrm{KCl}, 1 \cdot 71 \mathrm{~mm}-$ $\mathrm{CaCl}_{2} \cdot 2 \mathrm{H}_{2} \mathrm{O}, 1 \cdot 19 \mathrm{~mm}-\mathrm{KH}_{2} \mathrm{PO}_{4}, 1 \cdot 19 \mathrm{~mm}-\mathrm{MgSO}_{4} \cdot 7 \mathrm{H}_{2} \mathrm{O}, 25 \mathrm{~mm}-\mathrm{NaHCO}_{3}, 0.5 \mathrm{~mm}$-sodium pyruvate, $1 \mathrm{~mm}$-glucose, 100 units penicillin $\mathrm{G} / \mathrm{ml}, 50 \mu \mathrm{g}$ streptomycin sulphate $/ \mathrm{ml}$ and the amino acids, vitamins and trace elements of Ham's F10 medium (Ham, 1963; Kane \& Foote, 1970).

Biochemicals. The 2 types of commercial BSA (Sigma, London) used were normal BSA and defatted BSA from which fatty acids and other protein-bound contaminants had been removed by charcoal treatment (Chen, 1967). The trypsin Type 1 and the protease inhibitors $N$ - $\alpha$ - $p$-tosyl-Larginine methyl ester $\mathrm{HCl}$ (TAME), $N$ - $\alpha$-p-tosyl-L-lysine chloromethyl ketone $\mathrm{HCl}$ (TLCK), soya bean trypsin inhibitor Type 1-S, ovomucoid trypsin inhibitor Type 111-0 and $\alpha$-1-antitrypsin were from Sigma.

Experiment 1. The heat stability of the hatching-promoting factor in the BSA was examined. Embryos were cultured in defatted BSA, normal BSA and normal BSA heat treated at 65 or $80^{\circ} \mathrm{C}$ for $20 \mathrm{~min}$. Defatted BSA was used at $0 \cdot 1 \%$ and normal BSA at $1 \cdot 5 \%$.

Experiment 2. The ability of a protease, trypsin, to duplicate the effects of commercial BSA was examined. Embryos were cultured in $0.1 \%$ defatted BSA and levels of trypsin varying from 4 to $2500 \mathrm{ng} / \mathrm{ml}$.

Experiment 3. The ability of protease inhibitors to prevent complete hatching of blastocysts was examined. Embryos were cultured in $1.5 \%$ normal BSA either alone or with the protein-type protease inhibitors, soya bean trypsin inhibitor, ovomucoid and $\alpha-1$-antitrypsin, or the nonprotein-type inhibitors, TLCK and TAME. Inhibitors were dissolved in culture medium and added after 2 days in culture in order to localize their effects to the stage of blastocyst formation and hatching. The concentrations used were similar to those previously used in tissue culture experiments (Schnebli, 1975).

Statistical comparisons were carried out on the overall treatment responses using $\chi^{2}$ tests with the Yates' correction for continuity.

\section{Experiment 1}

\section{Results}

Heat treatment of the normal BSA significantly decreased its ability to promote expanding blastocyst formation and almost completely destroyed its ability to cause complete blastocyst hatching (Table 1).

Table 1. Effect of heat treatment of normal BSA on its ability to cause complete hatching of rabbit blastocysts cultured from the one-cell stage

\begin{tabular}{lcccc}
\hline & & & \multicolumn{2}{c}{$\begin{array}{c}\text { Heat treatment of } \\
\text { normal BSA }\end{array}$} \\
\cline { 5 - 5 } & $\begin{array}{c}\text { Defatted } \\
\text { BSA }\end{array}$ & $\begin{array}{c}\text { Normal } \\
\text { BSA }\end{array}$ & $65^{\circ} \mathrm{C}$ & $80^{\circ} \mathrm{C}$ \\
\hline No. of embryos & 49 & 44 & 47 & 43 \\
$\%$ Early blastocysts & $59^{* *}$ & 91 & $62^{* *}$ & $70^{* *}$ \\
$\%$ Expanding blastocysts & $31^{* * *}$ & 75 & $32^{* * *}$ & $33^{* * *}$ \\
$\%$ Hatched blastocysts & $0^{* * *}$ & 55 & $2^{* * *}$ & $0^{* * *}$ \\
\hline
\end{tabular}

All percentages are based on the total number of embryos in each treatment. 0.001

Significantly different from that for normal BSA : ${ }^{*} P<0.05,{ }^{* *} P<0.01,{ }^{* * *} P<$ 


\section{Experiment 2}

Trypsin levels of 20,100 and $500 \mathrm{ng} / \mathrm{ml}$ in the culture medium permitted a high proportion of hatched blastocyst formation in the presence of defatted BSA (Table 2). These hatched blastocysts usually contained both inner cell mass and trophoblast. However, they did not expand noticeably after hatching and all degenerated within $24 \mathrm{~h}$ after hatching.

Table 2. Effect of trypsin on growth of one-cell rabbit embryos to blastocysts

\begin{tabular}{lcccccc}
\hline & \multicolumn{7}{c}{ Trypsin conc. (ng/ml) } \\
\cline { 2 - 7 } & 0 & 4 & 20 & 100 & 500 & 2500 \\
\hline No. of embryos & 45 & 46 & 41 & 46 & 41 & 42 \\
$\%$ Early blastocysts & 62 & 57 & 71 & 52 & 54 & 5 \\
$\%$ Expanding blastocysts & 49 & $20^{*} \dagger$ & 66 & 43 & 54 & $5^{* *}$ \\
$\%$ Hatched blastocysts & 0 & 0 & $63^{* *}$ & $43^{* *}$ & $54^{* *}$ & 5 \\
\hline
\end{tabular}

All percentages are based on the total no. of embryos in each treatment.

Significantly different from that for the 0 concentration of trypsin, ${ }^{*} P<0.01,{ }^{* *} P<0.001$.

$\dagger$ The mean for this treatment is abnormally low due to the degeneration of blastocysts due to contamination in one replicate.

\section{Experiment 3}

The only protein-type protease inhibitor to reduce blastocyst hatching was ovomucoid and that only at the highest concentration of $2.5 \mathrm{mg} / \mathrm{ml}$ (Table 3). The highest level of TLCK and TAME significantly decreased early blastocyst, expanding blastocyst and hatched blastocyst formation, while the middle level of TAME significantly decreased both early and expanding blastocyst formation (Table 4).

Table 3. Effect of protein-type protease inhibitors on blastocyst formation and hatching

\begin{tabular}{llcccc}
\hline & & \multicolumn{4}{c}{ Normal BSA + protease inhibitor (mg/ml) } \\
\cline { 3 - 6 } Protease inhibitor & & 0 & $0 \cdot 1$ & $0 \cdot 5$ & $2 \cdot 5$ \\
\hline Soya bean trypsin inhibitor & No. of embryos & 50 & 43 & 49 & 46 \\
& $\%$ Early blastocysts & 64 & 63 & 73 & 67 \\
& $\%$ Expanding blastocysts & 52 & 51 & 67 & 63 \\
& $\%$ Hatched blastocysts & 22 & 19 & 20 & 30 \\
\hline Ovomucoid trypsin inhibitor & No. of embryos & 59 & 61 & 57 & 55 \\
& \% Early blastocysts & 68 & 70 & 74 & 67 \\
& \% Expanding blastocysts & 58 & 61 & 68 & 49 \\
& $\%$ Hatched blastocysts & 24 & 33 & 30 & $5 *$ \\
\hline \multirow{2}{*}{-1-Antitrypsin } & No. of embryos & 25 & 27 & 29 & 27 \\
& $\%$ Early blastocysts & 88 & 81 & 79 & 67 \\
& $\%$ Expanding blastocysts & 84 & 78 & 66 & 63 \\
$\%$ Hatched blastocysts & 56 & 59 & 50 & 41 \\
\hline
\end{tabular}

All percentages are based on the total no. of embryos in each treatment.

Significantly different from 0 level of inhibitor: ${ }^{*} P<0.05$. 
Table 4. The effects of the protease inhibitors TAME and TLCK on blastocyst formation and hatching

\begin{tabular}{llcccc}
\hline $\begin{array}{l}\text { Protease } \\
\text { inhibitor }\end{array}$ & \multicolumn{4}{c}{ Normal BSA + protease inhibitor $(\mathrm{mg} / \mathrm{ml})$} \\
\hline TAME & 0 & $0 \cdot 04$ & $0 \cdot 2$ & $1 \cdot 0$ \\
\hline & No. of embryos & 53 & 50 & 55 & 48 \\
& $\%$ Early blastocysts & 94 & 80 & $78^{*}$ & $44^{* *}$ \\
& $\%$ Expanding blastocysts & 92 & 78 & $73^{*}$ & $31^{* *}$ \\
& $\%$ Hatched blastocysts & 64 & 60 & 47 & $10^{* *}$ \\
\hline \multirow{2}{*}{ TLCK } & & 0 & $0 \cdot 02$ & $0 \cdot 1$ & $0 \cdot 5$ \\
\hline & No. of embryos & 20 & 26 & 25 & 37 \\
& $\%$ Early blastocysts & 81 & 73 & 82 & $0^{*}$ \\
& $\%$ Expanding blastocysts & 78 & 69 & 82 & $0^{*}$ \\
& $\%$ Hatched blastocysts & 56 & 54 & 50 & $0^{*}$ \\
\hline
\end{tabular}

All percentages are based on the total no. of embryos in each treatment. Significantly different from 0 level of inhibitor; ${ }^{*} P<0.05,{ }^{* *} P<0.001$.

\section{Discussion}

The results of these experiments do not support the idea that protease contaminants of the BSA directly cause blastocyst hatching or that non-protease contaminants stimulate production of an endogenous blastocyst protease which causes hatching. While trypsin mimicked the effect of the normal BSA in causing blastocyst hatching, these blastocysts degenerated rapidly in culture, unlike those formed in the presence of normal BSA.

None of the protease inhibitors tested seemed to inhibit blastocyst hatching in a specific manner. When blastocyst hatching was significantly inhibited this happened only at the highest concentration of the inhibitors and the inhibition of blastocyst hatching was accompanied by a reduction in formation of early and/or expanding blastocysts. This suggests that the inhibitory effect is either a non-specific toxic effect or else a general inhibitory effect on cell division. The hatching of rabbit blastocysts in culture is associated with an increase in cell number (M. T. Kane, unpublished data). This information plus the present data suggests that hatching of rabbit blastocysts in culture is due to a mechanical process whereby the expanding blastocyst forces its way out through a weak point in the zona and the thin mucin coat (usually less than $5 \mu \mathrm{m}$ in these experiments) rather than to an enzymic process. Photographs of blastocyst hatching have already been published (Kane, 1975). However, hatching of rabbit blastocysts does not occur in utero; instead the rabbit blastocyst expands and stretches the zona and the mucin coat (reviewed by Denker, 1977). There is evidence that digestion of blastocyst coverings in utero is carried out both by a blastocyst protease and by proteases present in uterine fluid (Denker, 1977), but blastocyst hatching in utero is probably prevented by the presence of a thick mucin coat (Kane, 1975).

One of the more intriguing possibilities to emerge as a potential function for uterine proteases is that they may act as mitogenic agents stimulating blastocyst growth. Proteases are known to have mitogenic effects on mouse embryos (Pienkowski, Solter \& Koprowski, 1974; Konwinski, Solter \& Koprowski, 1978). There are numerous reports of the mitogenic effects of proteases on cells in tissue culture, e.g. on mouse and human lymphocytes (Kaplan \& Bona, 1974), on chick embryo fibroblasts (Chen \& Buchanan, 1975) and on human lymphocytes (Mazzei, Novi \& Bazzi, 1966). Proteases may also be mitogenic for rabbit blastocysts and the present results with the protease inhibitors do not exclude this possibility. This is particularly true of the results with TAME, a 
competitive inhibitor of proteases and esterases (Kassell \& Laskowski, 1956), in which a decrease in blastocyst formation and expansion was present even at a relatively low concentration of inhibitor $(0.2 \mathrm{mg} / \mathrm{ml})$.

The factor in the commercial BSA that causes blastocyst hatching is shown to be heat-labile, being destroyed by heating at 65 and $80^{\circ} \mathrm{C}$. This provides only a limited amount of information as to its identity because heating would be expected to destroy a wide range of serum factors such as enzymes and vitamins. Heating not only abolished almost completely the formation of hatched blastocysts but also reduced the level of early and expanding blastocyst formation to that found with defatted BSA. This indicates that the factor concerned is one that promotes not just blastocyst hatching but also blastocyst growth.

We are now attempting to purify the hatching promoting factor from commercial samples of BSA and are also investigating the effects of a wide range of proteases and other enzymes on the rabbit blastocyst. Results to date indicate that although a number of proteases cause blastocyst hatching none is comparable to the BSA factor in promoting blastocyst growth.

This research was supported by a grant from An Foras Taluntais and the National Board for Science and Technology. I thank Mrs Patricia Commins for technical assistance.

\section{References}

Chen, L.B. \& Buchanan, J.M. (1975) The mitogenic activity of blood components. 1. Thrombin and prothrombin. Proc. natn. Acad. Sci. U.S.A. 72, 131135.

Chen, R.F. (1967) Removal of fatty acids from serum albumin by charcoal treatment. J. biol. Chem. 242, 173-181.

Denker, H.W. (1977) Implantation. The role of proteinases and blockage of implantation by proteinase inhibitors. Adt. Anat. Embrvol. Cell Biol. 53, 1-123.

Ham, R.G. (1963) An improved nutrient solution for diploid Chinese hamster and human cell lines. Expt Cell Res. 29, 515-526.

Kane, M.T. (1972) Energy substrates and cultures of single cell rabbit ova to blastocysts. Nature, Lond. 238, $468-469$.

Kane, M.T. (1975) Inhibition of zona shedding of rabbit blastocysts in culture by the presence of a mucin coat. J. Reprod. Fert. 44, 539-542.

Kane, M.T. \& Foote, R.H. (1970) Culture of two- and four-cell rabbit embryos to the expanding blastocyst stage. Proc. Soc. exp. Biol. Med. 133, 921-925.

Kane, M.T. \& Headon, D.R. (1980) The role of commercial bovine serum albumin preparations in the culture of one-cell rabbit embryos to blastocysts. J. Reprod. Fert. 60, 469-475.

Kaplan, J.G. \& Bona, C. (1974) Proteases as mitogens. The effect of trypsin and pronase on mouse and human lymphocytes. Expl Cell Res. 88, 388-394.

Kassell, B. \& Laskowski, M. (1956) The comparative resistance to pepsin of six naturally occurring trypsin inhibitors. J. biol. Chem. 219, 203-210.

Konwinski, M., Solter, D. \& Koprowski, H. (1978) Effect of removal of the zona pellucida on subsequent development of mouse blastocysts in vitro. J. Reprod. Fert. 54, 137-143.

Mazzei, D., Novi, C. \& Bazzi, C. (1966) Mitogenic action of trypsin and chymotrypsin. Lancet ii, 232.

Pienkowski, M., Solter, D. \& Koprowski, H. (1974) Early mouse embryos: growth and differentiation in vitro. Expl Cell Res. 85, 285-290.

Schnebli, H.P. (1975) The effects of protease inhibitors on cells in vitro. In Proteases and Biological Control, Vol. 2, pp. 785-794. Eds E. Reich, D. B. Rifkin \& E. Shaw. Cold Spring Harbor Laboratory.

\section{Received 23 December 1982}

